\title{
HELEN HUNT JACKSON'S RAMONA: THE ROMANCE THAT BECAME A TOURIST GUIDE AND SILENCED THE MESTIZA
}

\author{
Carolina Fernández Rodríguez \\ Universidad de Oviedo*
}

\begin{abstract}
This study focuses on American writer and activist Helen Hunt Jackson and aims to explain why her romance Ramona (1884), originally intended as a form of literary activism on behalf of California's Native Americans, failed to effect actual change in the situation of the state's indigenous population and, instead, ended up as an accomplice in the late $19^{\text {th }}$-century development of Anglo California. Said development brought along not only the advance of railroad companies, real-estate investors and the tourist industry, but, most poignantly, the displacement and consequent genocide of its Native inhabitants. All in all, the paper will prove that a social and political vision like Jackson's, weighed down by the systems of imperialism and capitalism, as well as the oppressive discourses of racism and sexism, was bound to entrench economic, sexual and racial inequalities despite its good intentions.
\end{abstract}

Keywords: Helen Hunt Jackson, California's Mission Indians, Literary Activism, Literature and Tourism, Spanish Fantasy Heritage, Mestiza Identity.

\author{
RAMONA, DE HELEN HUNT JACKSON: \\ EL ROMANCE QUE SE CONVIRTIÓ EN GUÍA TURÍSTICA \\ Y SILENCIÓ A LA MESTIZA
}

\section{RESUMEN}

Este artículo se centra en la escritora y activista estadounidense Helen Hunt Jackson y tiene por objeto explicar las razones por las que su romance Ramona (1884), concebido como una forma de activismo literario a favor de los nativo-americanos de California, fracasó a la hora de cambiar la situación de la población indígena del estado y se convirtió, en lugar de eso, en cómplice del desarrollo de la California blanca a finales del siglo xIX, el cual trajo consigo no solo el avance de las compañías de ferrocarril, las inversiones inmobiliarias y la industria turística, sino también el desplazamiento y el genocidio posterior de su población nativa. En definitiva, el artículo demostrará que una visión como la de Jackson, lastrada por los sistemas imperialista y capitalista y por los discursos opresivos del racismo y el sexismo, estaba abocada a afianzar las desigualdades raciales, sexuales y económicas pese a sus buenas intenciones.

Palabras Clave: Helen Hunt Jackson, indios de las misiones californianas, activismo literario, literatura y turismo, patrimonio español fantasioso, identidad mestiza.

DOI: https://doi.org/10.25145/j.recaesin.2020.81.13

Revista Canaria de Estudios Ingleses, 81; November 2020, pp. 193-215; ISSN: e-2530-8335 


\section{CALIFORNIA, HOME OF RAMONA}

In the summer of 2017, I was admitted by the Beatrice Bain Research Group at the University of California at Berkeley as a Visiting Scholar. Soon after arriving in Berkeley, I met an Anglo woman whose three-year old daughter was called Ramona, and was deeply shocked by the name, which, despite being Spanish, is considered terribly old-fashioned in Spain. Soon after this surprising anecdote, and while, as tourists will do, strolling around the city of San Francisco, I was once again taken aback by a street plaque that read: "Ramona Street." Now this had to mean something, but I did not know what. It was only after a few more days in California that a member of the Berkeley Meeting of the Society of Friends, Sue Friday, after hearing me say that I was planning to do some research on romances, told me that she was not a fan of the romance genre, but that there was one romance novel that she did like. The author, she told me, had married twice, and her second husband, William S. Jackson, was a renowned Quaker in Colorado Springs, Colorado, where he worked for the Denver and Rio Grande Railway Co and founded the El Paso Bank. The writer she had in mind was called Helen Hunt Jackson, and the title of the work she was talking about explained my previous shocking experiences. It was Ramona, of course.

These personal anecdotes certify what most Californians know for sure: "Oddly, the most important woman in the history of southern California never lived. Nor has she yet died. She is the fictional heroine of Helen Hunt Jackson's 1884 novel Ramona, and her mark on southern California's landscape, and on social memory in the region is indelible even today" (DeLyser 886). To this I could well add that not only is the southern Californian landscape affected by Jackson's Ramona, but also that of Northern California, as my experiences in the Bay Area attest. Indeed, there is a plethora of Ramona sites in the whole state of California: a Ramona Valley, where one can find a Ramona Valley Inn or a Ramona Valley Grill; dozens of Ramona Streets, apart from the one I saw in San Francisco, crisscross the towns and cities of this western state, as for example in Ventura, or in Palo Alto, to name but two; there are Ramona Elementary Schools, Ramona Libraries, Ramona shops, and an endless number of Ramona products; needless to say, there are Ramona kids, too. As one person put it in the 1920s, "I doubt if there is any town in Southern California that does not boast of a street, hotel, garden, park, or public place named

* Research for this paper has been carried out thanks to the University of Oviedo (Spain), which granted me the funds necessary to spend the summer of 2017 as a Visiting Scholar at the University of California at Berkeley, where I was integrated into the Beatrice Bain Research Group, and to professor Paloma Fresno Calleja, of the Balearic Islands (Spain), who invited me to participate in the research project "The Politics, Aesthetics and Marketing of Literary Formulae in Popular Women's Fiction: History, Exoticism and Romance," supported by MINECO/AEI/FEDER, UE (FFI2016-75130-P). But first and foremost, my gratitude goes to Sue Friday, the Berkeley friend who revealed to me the existence of Ramona. 
'Ramona'” (qtd. in DeLyser 889). Again, I would add that nearly as much might be said of Northern California as well.

\section{HELEN HUNT JACKSON, AN ACTIVIST ON BEHALF OF NATIVE AMERICANS}

The author of the novel that triggered the Ramona craze that continues well into the $21^{\text {st }}$ century was a woman writer from Amherst, Massachusetts, called Helen Hunt Jackson (1830-1885), although she published some of her works under various pseudonyms: “'Marah,' 'Rip Van Winkle,' 'H.H.' and 'Saxe Holm”' (Whitaker 56); in many cases, too, she resorted to the complete anonymity of "No Name" (Dobie 93). She was first a poet, later on a novelist and for part of her adult life an activist. In 1879, after hearing a lecture in Boston by Chief Standing Bear, of the Ponca Tribe, she grew interested in Native Americans (Mathes, "Helen Hunt Jackson and Southern" 263). Moved by Standing Bear's description of the forcible removal of the Ponca from their reservation in southeastern Dakota to a reservation in Oklahoma (Nevins 272), she carried out an investigation into government misconduct in regards to Native Americans, and subsequently began to denounce said misconduct. Her work on behalf of the Ponca tribe took the form of petitions, fund-raising, letters to the editor of the New York Herald Tribune and articles for the New York Independent. ${ }^{1}$ Besides, she published A Century of Dishonor (1881), an expose of the plight of Native Americans in which, apart from documenting the conditions they were made to live in, she denounced federal Indian policy and called for significant reform in government policy toward Native Americans. ${ }^{2}$

Unabated by the lack of significant repercussions of her work, Helen Jackson continued gathering evidence on the mistreatment of Native peoples in the US. In 1881-1882 she toured southern California gathering material on the so-called Mission Indians ${ }^{3}$ for a series of articles commissioned by Richard Watson Gilder of Century Magazine (Mathes, "Helen Hunt Jackson and the Southern" 263). Her Quaker

${ }^{1}$ An in-depth analysis of Jackson's involvement in the so-called Ponca Controversy is offered in Mathes, "Helen Hunt Jackson and the Ponca."

2 Jackson's reformist activities have been thoroughly studied by Valerie S. Mathes ("Nineteenth Century Women" and "New York Women") in the context of 19th-century women's Indian reform movements and associations; among these, there stands out the Women's National Indian Association (WNIA), of which Jackson was a member for a brief period before her death in 1885 (Mathes, "Helen Hunt Jackson and the Ponca" 53).

${ }^{3}$ I feel compelled to use the terms "Mission Indians" and "Indians" in this paper, despite their incorrectness, as they were the labels employed by Helen Hunt Jackson and her contemporaries back in the $19^{\text {th }}$ century. I nonetheless quite agree with Gonzalez's conviction that said expressions should be critically read: “The 'Mission Indians' moniker lumped together the tribal nations of southern California forcibly Christianized in the colonial Spanish mission system. Although I can scarcely avoid using the hegemonic terminology of the era in my discussion of Jackson, I critically acknowledge how such labelling serves as a colonial representational strategy to symbolically 
husband, the prominent Colorado entrepreneur William S. Jackson, accompanied her for a portion of the tour. ${ }^{4}$ In 1882 her concern with Native Americans was acknowledged by US authorities, who appointed her special commissioner of Indian Affairs in California, a position that provided her with additional opportunities to travel and observe. Thus, "[w]ith coagent Abbot Kinney, [Jackson] spent six months in 1883 travelling by wagon or mule, visiting Indian settlements and observing the deplorable conditions under which Indians lived" (Smith-Baranzini 157). Thanks to these travels around California, Jackson deepened her knowledge of Mission Indians, the label often used to refer to California's Indigenous peoples, whom the Spanish colonizers had forced to move from their traditional dwellings, villages, and homelands to live and work at 15 Franciscan missions stretching from San Diego (1769) to San Francisco (1776), the so-called Camino Real.

After gaining independence from Spain (1821), and later on in the years of Mexican California, the Mexican government provided for resident Indians to continue to occupy mission lands, but in 1833 Mexico secularized the missions and subsequently gave or sold the lands to non-Natives. Many of the Mission Indians worked on the newly established ranchos with little improvement in their living conditions. Their situation further deteriorated after the Mexican-American War and the Treaty of Guadalupe-Hidalgo that settled the dispute between the two contending nations. In fact, in US California (after 1848), Anglos often expelled "Californios" (the colonial residents of Spanish California) from their ranchos and the US disregarded Mission Indian occupancy claims. A look at the population decline of the state's Native peoples between the $18^{\text {th }}$ and the $19^{\text {th }}$ centuries offers appalling proof of the fatal impact of first Spanish, then Mexican, and finally US rule over California. In 1769 there were about 300,000 Native peoples; by 1821, they had been reduced to 100,000 as a consequence of the Spanish Empire; by 1860, Mexican independence and the Gold Rush of 1848, which brought disease, starvation, homicide and a declining birthrate, had reduced the number of Indigenous peoples to 30,000; in 1900, a California saturated with Euro-American incomers has been left with some 15,377 Native individuals (Padget 839-840).

On realizing the unacceptable situation of California's Native population, Jackson resolved to do something to attract attention to the problems of Mission Indians. Together with Abbot Kinney, she filed a 56-page report in July 1883 (Report on the Condition and Needs of the Mission Indians of California) $)^{5}$ including

deterritorialize specific tribal nations and thus to delegitimize their past and present territorial claims" (458).

${ }^{4}$ Helen Hunt Jackson met William S. Jackson in the winter of 1873, when she travelled to Colorado Springs, Colorado, to try and improve her health; the couple was married in a Quaker ceremony in October of 1875 in New Hampshire (Marsden 110). They "made their home in Colorado Springs, which Mrs. Jackson regarded as her legal residence from then on, although she actually spent most of her last five years in California" (Arlt 106).

5 John R. Byers ("The Indian Matter") has thoroughly explained the close relation between Jackson's 1883 report and her 1884 novel, pointing out the similarities between the descriptions of 
eleven points and recommendations about the California Indians (Mathes, "Helen Hunt Jackson: Official" 68). For example, it recommended extensive government relief for Mission Indians, including the purchase of new lands for reservations and the establishment of more Indian schools. A bill embodying her recommendations passed the US Senate but died in the House of Representatives. It would therefore be appropriate to say that, all in all, it fell on deaf ears. Just as A Century of Dishonor (1881) had done little to improve the situation of the Ponca Tribe, her 1883 report was similarly ineffectual in bringing about actual improvement. However, Jackson's resolve to effect change remained unfaltering, though she did realize the need to modify her tactic. Given that letters to the editor, essays and reports had had little impact, it became clear to her that "only an emotional plea would attract popular sympathy toward the Indians" (Smith-Baranzini 157; emphasis added). Her "emotional plea" took the shape of Ramona: A Story (1884), a novel about Indian life in Southern California with which "Jackson hoped to do for the southern Californian Indian what Uncle Tom's Cabin had done for the African-American slave" (Stevens 158). ${ }^{6}$ Regardless of the fate that awaited her oeuvre on behalf of Native Americans, a year after the publication of Ramona, in 1885, in a letter to Thomas W. Higginson, Jackson expressed her satisfaction at the pieces of writing she had produced, while hinting at the influence her marriage to a Quaker may have had on her dedication to the Native cause: "You have never fully realized how for the last four years my whole heart has been full of the Indian cause-how I have felt, as the Quakers say, 'a concern' to work for it. My 'Century of Dishonor' and 'Ramona' are the only things I have done of which I am glad now" (qtd. in Mathes, "Helen Hunt Jackson and Southern" 272). This might explain why those are the only two of her works that she signed her full name to (Dobie 94).

real-life locations from her report and of fictive settings in Ramona, as well as highlighting the unfair situations that befall both real Native Americans and her Indigenous characters. He thus proves that the research Jackson carried out in her travels around Southern California was first transmitted in her report and subsequently in her novel.

${ }^{6}$ Valerie S. Mathes has called attention to the irony that, in the long run, Jackson's 1883 report may have left a more enduring legacy in terms of legislation reform than Ramona, which, as will be explained, failed to obtain the expected results. In particular, Mathes argues that the recommendations given in the 1883 report "became the foundation of legislation setting aside thousands of acres of land on over thirty reservations-reservations that still exist and can be traced directly to [Jackson's] work" ("The California Mission" 339). She is specifically referring here to the 1891 "Act for the Relief of the Mission Indians in the State of California," described by Quaker Albert K. Smiley as "the bill of Mrs. Jackson, with some modifications" (qtd. in Mathes, "The California Mission" 341). 


\subsection{The NOVEL, MEDiA ADAPTATIONS AND FANTASY HERITAGE}

Jackson's Ramona, written at the Berkeley Hotel in New York City, was first published in serialized form in the Christian Union beginning in May 1884 (Mathes, "Helen Hunt Jackson: Official" 75); it was later on published by Roberts Brothers in Boston in November (Mathes, Helen Hunt Jackson and Southern" 270-271). Set in Southern California after the Mexican-American War, it portrays the life of a mixed-race Scots-Native American orphan girl, Ramona, a dark-haired, blue-eyed 19-year-old beauty who suffers racial discrimination and hardship. She is first abused on the Moreno Ranch, whose owner, the stern widow Señora Moreno, of Castilian descent, has always resented Ramona's mixed-race origin, and the fact that she was forced to become Ramona's foster mother and to raise her together with her own son, Felipe Moreno. Ironically, the latter has been in love with Ramona for as long as he can remember. Ramona, for her part, has been kept ignorant of her mixedblood heritage by her foster mother, and she feels only sisterly love for Felipe. She learns about her Indian blood soon after falling in love with Alessandro Assis, a young Luiseño ${ }^{7}$ sheepherder who was often hired by Señora Moreno. When Ramona expresses her desire to marry Alessandro, Señora Moreno opposes the marriage on the grounds of miscegenation and condemns the lovers to exile. On leaving the Moreno ranch, the couple is forced to move from one location to another, constantly plagued by Anglo advancement, brutality and land-takings, which results in the couple's displacement, uprooted ness, disease, hunger, the death of their first baby and, later on, of Alessandro himself, who is shot by an Anglo settler who falsely accuses him of horse-stealing. For Ramona, respite from Anglo-European encroachment comes rarely, and only from two sources: her piety, reinforced by the character of Father Salvierderra, the benevolent Franciscan priest from whom Ramona seeks constant counselling, and her love, first for the Native Alessandro, and ultimately for the Californio Felipe Moreno. But it will be Felipe who, in the end, will rescue her from a life of poverty and ignominy among Cahuilla Indians by marrying her and giving her a home in Mexico and plenty of children.

The novel soon became immensely popular, "an instant and tremendous success" (Arlt 107). During her own time, Jackson enjoyed the praise of the masses, and some of the greatest literary figures of the period, like Emerson and Dickinson, also admired her. The latter, in particular, a childhood friend with whom Jackson corresponded for a number of years, declared that "Helen of Troy will die, but Helen of Colorado, never" (qtd. in Byers, "Helen Hunt Jackson" 143). To this day,

7 The term "Luiseño" is commonly used to refer to the Payómkawichum, a group of Native Americans who inhabited the coastal area of southern California. After the establishment of Mission San Luis Rey de Francia in 1798, Natives living in the vicinity of the mission began to be called Luiseños by Spanish missionaries. 
Jackson's Ramona has had more than 300 printings (Byers, "Helen Hunt Jackson" 146), with a variety of covers that attest to the multiplicity of readings that each editor and publishing house has deemed appropriate to instigate, though, generally speaking, five approaches seem to be favored. There are covers that feature a girlish Ramona of unmistaken Caucasian descent, like the image chosen by CreateSpace Independent Publishing Platform for their 2014 edition, or covers that show a youngish Scottish-like Ramona, which is the image selected for the 2016 edition by CreateSpace Independent Pub; other covers, however, prefer to cast Ramona as a young woman of Spanish decent, as is the case of the Signet Classics 2002 edition. All of these seem to prefer to imagine a Ramona who is mostly a European character, thus shaping the Ramona myth in a way that late $19^{\text {th }}$ and early $20^{\text {th }}$ century Anglo settlers in California would find more appealing. There are other covers, however, that opt for the unapologetically Indian woman, an example of which is offered by the Halcyon Press 2010 edition, while others choose the Native American Ramona, but do so more symbolically, as The Modern Library Classics 2005 edition, which rather than showing Ramona's full or upper-part body, simply pictures a long, dark braid. For the editors of these editions, Ramona's mythical force lies in her Indigenous connection with the land, and when it comes to imagining California's past, they favor the Native thread over the European one. Lastly, there exist a number of covers that avoid the perhaps more problematic decision of picturing Ramona's mixed-race ancestry one way or another by choosing, instead, to depict a landscape scene, as do both the Signet Classics 2002 Kindle edition and the Signet Classics 2010 version. Significantly, the landscape chosen in these covers is an empty one, which would imply the land's readiness for Anglo settlement, and Ramona, absent in them in either her European or her Native impersonation, is nothing but a ghost that confers an exotic, quaint and romantic aura onto the land, one that never implies any sort of obstacle, but simply an elusive enticement.

Besides its popularity in the novel format, Ramona has enjoyed great success across various genres. In fact, it has been adapted into film and other media on numerous occasions. In 1910, D.W. Griffith directed Ramona, a 17-minute silent short starred by Mary Pickford; Donald Crisp's 1916 film Ramona is partially lost; the 1928 take, Ramona, directed by Edwin Carewe, features Dolores del Río and Warner Baxter, while the 1936 version, Ramona, directed by Henry King, is starred by Loretta Young and Don Ameche; the Screen Guild Theater produced a 1945 radio broadcast, and Víctor Urruchúa's film Ramona came out a year later, in 1946; more recently, in 2000, a Mexican telenovela called Ramona saw the light. To round off this list of media adaptations, it is worth pointing out that since 1923 a Ramona play has been performed annually outdoors "under the auspices of the Los Angeles Chamber of Commerce" (Rawls 352): "The towns of Hemet and San Jacinto united in 1923 to launch the Ramona Pageant, a full-scale outdoor dramatization of the novel that has run nearly every year since" (DeLyser 889), thus becoming the largest and longest running outdoor play in the United States and the official state play of the state of California.

But the phenomenal success of Jackson's Ramona is not only measured in its numerous editions or its transmedia adaptations, notwithstanding their 
large numbers. As a matter of fact, the novel's greatest legacy has been said to lie in its capacity to spawn not simply a "fantasy heritage," a term coined by Carey McWilliams in 1949 to describe "the Anglo-American's propensity to romanticize and mythify the white European, Spanish presence in the American Southwest" (del Castillo 3), but more specifically, a "Spanish Fantasy Heritage" (Padget 835). In fact, it has been argued that the novel's sentimental portrayal of Mexican colonial life contributed to establishing a unique cultural identity for the state of California. ${ }^{8}$ As its publication coincided with the arrival of railroad lines in the region, countless Anglo tourists fled to Southern California to see the locations of the novel. They were eager to experience with their own eyes the romanticized vision of Californio livelihood that the novel gave, and to revel in the nostalgia for genteel Spanish California that it fostered. For them, it seemed to matter that the book mythologized the Spanish colonial mission system by promoting the idea that the Mission Indians were happy and well protected by the benevolent Spanish priests like Father Salvierderra and the land-owners, or hacendados, of Castilian descent like Señora Moreno. Indeed, the book carried out a "beatification of the Franciscan missionary effort in California" (Padget 852) and validated "not only the social and economic inequalities on which elite Californio society was based before and immediately after the U.S.-Mexican War but also the social and economic inequalities that prevailed in turn-of-thecentury American society" (Padget 834). In so doing, the novel gave shape to a form of "California pastoral" (Padget 840) that thousands of Anglo tourists became enraptured with. In the words of Glen Gendzel:

By embroidering her story with Spanish-themed nostalgia, Jackson unwittingly supplied Los Angeles writers with the raw material for a competing mythology. Ramona's depiction of Edenic bliss before the American conquest marked the first appearance of a new cast of characters in California historiography. Here were the dashing rancheros, courtly caballeros, enchanting señoritas, and most of all, the noble Spanish padres, represented as devoted missionaries who lavished Indians with loving kindness and built a chain of elegant missions up and down the California coast. (66)

\footnotetext{
${ }^{8}$ Yolanda Venegas uses a slightly different phrase to encapsulate the same idea, i.e., "the Spanish-heritage myth," which, in her words, offered uprooted Euro-American settlers in California "an epic antiquity, a California Plymouth Rock as ancient (and pure-blooded European) as the nation's traditional cultural centers in Boston and New York." Besides, "California's 'pure-blooded' Spanish heritage, complete with its missions, pious priests, and 'humble Indians,' provided Euro-Americans with antiquity and a sense of stability in a newly racialized California" (67).

9 Yolanda Venegas has similarly criticized Ramona's "nostalgic presentation of missionization," and its refusal to portray "the presidio compound and the mission complex during the colonial period" as "integral components of a feudal-like forced labor system," thus failing to acknowledge the complicit relationship between the church and the military: "Franciscans subsidized the military by providing the food and other supplies during the colonization effort" (73). Moreover, Venegas denounces Jackson's choice not to inscribe Native Californians' steadfast resistance strategies to Spanish colonization, which included, among others, "labor strikes, subversion of agricultural production," and "escape from the missions" (73).
} 
Thus was born the exotic fantasy that countless of Anglo migrants at the end of the $19^{\text {th }}$ century were to take solace in while settling in California. Thus was history translated into fantasy heritage, through a process that entailed selection, distortion, bias, and fabrication on the part of a number of agents, among which Ramona, if unwittingly, played a major role, as it came to epitomize what anthropologist Renato Rosaldo calls "imperialist nostalgia," or "morning for what one has destroyed" (qtd. in Gendzel 76). Indeed, the very same Anglo settlers, many of them Midwesterners, and tourists that flooded the state at the turn of the century and virtually wiped out its Indigenous people, simultaneously rejoiced in its Spanish fantasy heritage, while mostly ignoring the mestizo population who strove against their encroachment. That "myth and fantasy play an unusually large role in the social construction of all travel and tourist sights" (Rojek 53) seems to apply with exquisite precision to the case of Ramona and Southern California.

\subsection{Historical CONTEXT AND Literary GENRES}

If Jackson's Ramona has fascinated dozens of readers and critics ever since its publication, it is in part due to the abysmal gap between the author's noble intentions when she set up to write it, and the dismal results. In a letter to friends in Los Angeles, Jackson expressed her desire to write the "emotional plea" already referred to: "I am going to write a novel, in which will be set forth some Indian experiences in a way to move people's hearts. People will read a novel when they will not read serious books" (qtd. in DeLyser 891). The limited success of her nonfiction work had convinced her that the story of the Mission Indians would reach a wider audience if told in fictional form, which explains why in a letter to W.H. Ward, the editor of the New York Independent, she similarly stated her intention to write a novel that would encapsulate her activism on behalf of California's Native peoples, following the example set by Uncle Tom's Cabin: "If I can do one hundredth part for the Indians that Mrs. Stowe did for the Negro, I will be thankful" (qtd. in DeLyser 891). Similarly, in a letter to Amelia Stone Quinton, the president of the Women's National Indian Association, she hinted at her intention to follow Mrs. Stowe's precedent: "I do not dare to think I have written a second Uncle Tom's Cabin-but I do think I have written a story which will be a good stroke for the Indian Cause" (qtd. in Mathes, "Helen Hunt Jackson and Southern" 271). With Ramona, it seems unequivocally clear, she meant "to make us sick to our stomachs and angry over the treatment of the ex-mission Indians of southern California and to make us understand the lawlessness of the Americans and their occupation of California" (Monroy 139).

Jackson based her story loosely on real people, places and events that she had seen or learned about during her travels in southern California. In a letter to Thomas Bailey Aldrich, she herself states that "[e]very incident in Ramona [...] is true. A Cahuilla Indian was shot two years ago, exactly as Alessandro is-and his wife's name was Ramona" (qtd. in Mathes, "Helen Hunt Jackson and Southern" 271). But in the transposition from real life into fiction she had to make a number of decisions that negatively influenced her authorial intention, making it go awry. 
The historical period in which she wrote it is also to blame for this derailing. As already mentioned, in the 1880s California sees the spectacular development of the railroad. Various competing companies had reached the south of the state, which triggered a plummeting of railroad fares; this, in turn, was followed by massive real-estate speculation. Together, both facts gave rise to a colossal wave of incoming tourists and home-seekers. The region was then rapidly Anglicized and it underwent immense social change and urban growth (DeLyser 888). Thus the historical context contributed to the novel's phenomenal success. Ironically, thanks to its success, this unfortunately well-timed novel ended up participating in the further dispossession of the very same people it had set itself to save.

As for the literary decisions Jackson made in writing the story of Ramona, there stands out the question of the novel's various generic adscriptions to regional fiction, the sentimental novel, and the romance. First, Ramona can be adequately placed under the genre of regional fiction, which in the $19^{\text {th }}$ century served as an important stimulant to domestic tourist travel: "regional fiction's picturesque portrayals of 'remnant' cultures found tremendous appeal. And as domestic tourism rose first in popularity and then in affordability, Americans began to explore their own country in increasingly large numbers, adding literary shrines such as Ramona landmarks to the list of canonical tourist attractions" (DeLyser 891). Second, Jackson's novel qualifies as a sentimental novel, ${ }^{10}$ in line with other similar texts written in the $18^{\text {th }}$ and the $19^{\text {th }}$ centuries. ${ }^{11}$ Ramona, in fact, has been described as "a quintessential sentimental heroine, standing in a long American tradition of female characters who exercise sympathy" (Havard 105); she is "a young woman of feeling," uninterested in serious study or deep thought, "simple, joyous, gentle," comparable to "a clear brook rippling along in the sun" (Havard 105). Jackson, like other authors of sentimental novels, believed that "in order for someone to exercise sympathy for another, that someone must imagine him or herself to occupy that other's position" (Havard 102). Reassured by this conviction, Jackson believed her novel was to be a call for people to imagine themselves in the position of the abject Native American. Ramona would be, she hoped, a sort of battle cry that would first call attention to the plight of California's Native peoples, and would then trigger social and political action on their behalf.

But the novel's adscription to the genre of regional fiction did not serve to direct Anglos' attention to Indigenous people's dispossession, so mush as to attract

${ }^{10}$ For John Havard, given that Ramona portrays the recurrent dispossession of the protagonist couple and their various uprootings, Jackson's work is, in effect, a novel that "takes the form of a sentimental travel narrative" (107).

${ }^{11}$ For example, in her article on José Martí's reading of Jackson's Ramona, Susan Gillman refers to Harriet Beecher Stowe's Uncle Tom's Cabin (1852) and also to "Cuban Gertrudis Gómez de Avellaneda's abolitionist Sab (1841)," and "the Peruvian Clorinda Matto de Turner's pro-indigenista Aves sin nido [Birds without a Nest] (1889)" as examples of $19^{\text {th }}$-century women intellectuals who "aligned themselves, and their national visions, with the racially oppressed" (94) and, in so doing, produced novels that some might consider as "sickly sweet or sentimental" (95). 
herds of tourists to Southern California: "Rather than prompt its readers to search out social injustice, Ramona's success sent them looking for the places where the novel's characters had lived" (Stevens 161). For its part, Ramona's belonging in a long tradition of sentimental heroines further prevented Jackson from accomplishing through literature what she had been unable to achieve through direct political action. Indeed, Ramona's simple, pious, and gentle nature stripped her character of any political force. As Kevin Starr has put it, in Ramona, "sentiment overcame outrage" (qtd. in Gendzel 65), which undercut Jackson's authorial intention. Though Jackson's heroine was meant to move Anglos to empathize with Native Americans, she actually led them to focus almost exclusively on the romantic elements that abound in her story. In the words of Valerie Mathes: "Instead of being perceived as an indictment of the assault of Anglo California society upon the California Indians, [Ramona] was seen as a romantic love story that became a stock symbol of Southern California chambers of commerce and tourist bureaus" (Helen Hunt Jackson $\mathrm{x}$ ).

For her novel to be converted into a conventional romance, Jackson had to make her characters acceptable to her audience. As seen, she wanted them to be Mission Indians who would inspire Anglo readers to feel sympathy for Indigenous peoples in California, but she could not make them "real" Mission Indians and, simultaneously, "palatable" for an Anglo audience. Thus, neither of her main characters, Ramona and Alessandro, are Mission Indians who ring authentic. To start with, Ramona is part-white, and she has traits that $19^{\text {th }}$-century Euro-Americans could find appealing, namely, that she is extremely pious and kind. Of equal importance is the fact that, like many other Californians, she is a mix, a cross, but she possesses great physical beauty and her blue eyes help her pass for white: "She is Europeanized and, in her case, her mysterious Indian origin only serves to exoticize her. Ramona is beautiful, strange, devoted, and uncomplaining-what more could a man want?" (Monroy 143; emphasis added).

For his part, Alessandro is a full-blooded Indian, but he is superior to the average Mission Indian: he can read, play the violin, and has, surprisingly, neither a Native nor a Spanish name, but an Italian one. His skin color is so light that he does not look like an Indian. Paradoxically, his own tribe respects him precisely because of these unusual traits. In the words of John Havard, "Alessandro, who is educated and somewhat European in his ways, is an atypical Cahuilla Indian" (105; emphasis added). His talent for music, his religiosity, and his sensitive, refined, virtuous, and tender nature make him a fantasy figure for Victorian women, "a domesticated man" (Monroy 143). In other words, both Ramona and Alessandro are "fantasy" romance characters (she, the uncomplaining and stunningly beautiful heroine; he, the sensitive and caring Beta hero); besides, rather than authentic Mission Indians, there is general agreement that they look like Europeanized Indians. ${ }^{12}$ The main characters' lack of

12 Despite his being Europeanized, it should nonetheless be noted that Alessandro, like his father before him, goes insane and dies, which, according to Yolanda Venegas, suggests that Native Americans are "unfit for the modern world, inevitable victims of Manifest Destiny" (74). 
authenticity and romance-like heroic status made it possible for many readers to lose "track of the boundaries between the book's story and the reality that it purported to describe" (Stevens 161). In keeping with this, "Ramona's success as a romance undercut its effectiveness as an exposé of the problems of California's Indians. For most Americans, Southern California and the Mission Indians simply provided an interesting setting and exotic characters for a conventional love story" (Stevens 161).

\subsection{THE TOURIST INDUSTRY, PHOTOGRAPHY AND COMMODIFICATION}

Ramona's deviation from battle cry into romance is not exclusively attributable to the historical context in which the novel was written and the literary genres it was modeled on. The tourist industry soon came to profit from the novel in as much the same way as the businesses of real-estate development and railroad communications were doing. Photography, film, and, ultimately, commodification supported California's nascent tourist industry while helping to cancel Ramona's potential as a call to action in favor of Native Americans. In the end, the novel was entrenched as a love story that could make wonders, money-wise, while working in compliance with capitalism. Indeed, promoters of California as a tourist destination and place of residence "found photography to be one of their most important tools in transforming Ramona the social problem novel into Ramona the tourist attraction. Photographers eagerly recorded images of any person, object, or location that could have had a conceivable connection to the story" (Stevens 162). Thousands of photographs were taken and sold of places that were said to have been the exact settings where the characters had been born, raised, married, etc. And it was thus that "[t]he belief that characters and locations in the novel must correspond to real persons and real places became part of the culture of tourism in southern California" (Stevens 162).

Of the novel's settings, one of the easiest places to recognize in real life was the San Gabriel Mission, said to be Ramona's birthplace. By the end of the $19^{\text {th }}$ century, the missions of $E l$ Camino Real had been for some decades on the verge of crumbling down, ${ }^{13}$ but they were now beginning to receive renewed interest as potential tourist destinations and, ironically, as solid reminders of California's fantasy heritage. Though they can be considered the sites of the Indigenous peoples' genocide, they were nonetheless chosen to impersonate the "padre myth" (Gendzel 69), that is, the idea that during the Spanish era and under the mission system, "California was the happiest country in all the world," as in those days "people were not concerned with the strenuous materialism and commercialism of modern life" (McGroarty, qtd. in Gendzel 69). As Gendzel has put it, "[o]nly a vivid imagination could endow Spanish California with 'romance,' given the isolation, rough conditions,

\footnotetext{
13 "The missions had long since fallen into ruin by the time Jackson toured southern California in 1883” (Gonzalez 447).
} 
and shocking Native American death rates that prevailed at the time." In fact, he continues, [t] he missions probably stand closer in comparison to concentration camps than to the happy religious communes of Spanish mythology" (Gendzel 71). Regardless of the myth, many late $19^{\text {th }}$-century Anglo tourists disregarded the historical genocide of Indigenous peoples under the mission system, and chose instead to stick to the romanticized myth. ${ }^{14}$ In this context, the San Gabriel Mission was to occupy a special position among the missions, since it could be related not just to El Camino Real, but also to Jackson's Ramona.

Other settings acquired prominence thanks to their connection with the novel. The real-life Camulos Ranch, for instance, became the first contender for "Home of Ramona," or the fictive Moreno Ranch. It was conveniently located within walking distance of a station of the Southern Pacific Railroad. A mere two-hour train ride from Los Angeles took tourists through beautiful country to this ranch owned by the del Valle family. Photographers visited the ranch and made hundreds of photographs which were later on reproduced in magazines, tourist brochures, illustrated editions of Ramona, and as individual prints: "With little regard for the fact that Camulos was a private home, sightseers swarmed over the grounds, picking flowers and fruit, stealing souvenirs, invading the house, and generally offending residents with their 'Boston' manners" (Stevens 164). Owners of Camulos Ranch were first overwhelmed by the avalanche of tourists, but eventually they "used their rancho's notoriety to their benefit, marketing their citrus under the 'Home of Ramona' label, which featured an image of their by-now-famous south veranda" (DeLyser 896). In D.W. Griffith's 1910 first film version of the novel, Rancho Camulos featured prominently. For the first time in motion-picture history, a film director was thus giving screen credit to the location: "Camulos had become so important as the Home of Ramona that Griffith's film would have lacked authenticity without it" (DeLyser 900). Ironically, then, the film gained "authenticity" by being filmed on a location that had been commercially chosen to represent the novel's setting; in other words, fiction came to confer validity to fiction, and, ultimately, to offer considerable revenue both to the owners of the ranch and to the railroad company that promoted it as the Moreno Ranch.

Greed for profit gave rise to a second contender for Ramona's home: Guajome Ranch. The Southern Pacific's rival, the Santa Fe Route, took a special interest in this ranch, which it promoted as the "real home of Ramona" (Stephens 165). The chapel, the washing place and the sheep-shearing place on Guajome Ranch were locations that closely matched descriptions in the novel; moreover, this ranch was

${ }^{14}$ For more information on the so-called "Mission Myth," it is advisable to read James J. Rawls's "The California Mission as Symbol and Myth." This 1992 article offers a panorama of the evolution of the different attitudes that travelers, historians, journalists and others have had in regards to California's Franciscan missions, from the discrediting reports of Spain's imperial rivals in the $18^{\text {th }}$ century, to the romanticization of the missions as a symbol of the state's golden age in the late $19^{\text {th }}$ century, without forgetting Indigenous American's “indictment of the mission's system destructive effects on the native peoples" (358) from the 1980s on. 
only a mile and a half from the San Luis Rey Mission, a place frequently mentioned in the novel (Camulos Ranch, unlike the home in the novel, is not near Mission San Luis Rey). It is true that "[t]he owner [of Guajome Ranch] complained that he had to re-roof the house because photographers had broken many tiles climbing up to find the best shot of the patio" (Stevens 166), but the railroad company profited from these unintended consequences; besides, through this other ranch, another mission, that of San Luis Rey, could likewise capitalize on the proximity to Ramona's supposed home.

Estudillo House or La Casa Larga in San Diego's Old Town was subsequently chosen as Ramona and Alessandro's wedding place "through a combination of popular lore and the efforts of the owners of the Hotel del Coronado" (Monroy 137). Real-estate and light-rail developer John D. Spreckels bought the run-down adobe already popularly known as "Ramona's Marriage Place" and restored the building in 1910 (DeLyser 889). Picture postcards displayed "recently planted palms trees and imported agapanthus from Africa and the begonias from South America in its garden" (Monroy 137). Thus, photography was once again used to confer verisimilitude to a setting in a doubly paradoxical move: the adobe had been chosen because it seemed convenient to boost some businesses, not on account of any specific reference to Casa Estudillo in Jackson's novel, and the rehabilitation of the building was carried out without any concern for historical accuracy, respect for Indigenous architectural construction techniques, or autochthonous landscape design. Casa Estudillo was one among countless of examples of the power of photography to create "its own truth," in a process perfectly summarized by Errol W. Stevens:

Once such a place had been identified as part of the Ramona story, it underwent a transformation. No longer was it merely a ranch, adobe, or even a run-down old building, but became one of those special places where Ramona lived, got married, or went to school. Thus transformed from fictional location to a place in the real world, the site became a tourist attraction. Because it was a physical entity, photographers could take pictures of it. In the odd way that photography creates its own truth, the resulting images validated the authenticity of the story. (167)

Casa Estudillo was "upgraded" with a souvenir shop which sold dried flowers from the courtyard, teaspoons, postcards, toothpick holders, letter-openers, ash trays, salt-and-pepper shakers, napkin rings, and pocket notebooks, among countless of other Ramona curios. Couples could even marry in the restored chapel where the fictitious Ramona and Alessandro were said to have taken their vows. Tourists were encouraged to buy souvenirs, and thus contribute to the success of this particular business, but also to leave something of themselves behind (coins in a wishing well, notes, etc.) (DeLyser 898-899). In this way, meaning was gradually invested in objects and places, and tourists began to feel an intimate connection, probably an "authentic" one, in their view, with Estudillo House, and, more generally, with the Ramona of their fantasy heritage.

The widespread obsession to relate the novel's fictive settings to actual locations was taken one step further when photographers and tourists alike decided 
to go for the "real" Ramona. Many claimed that a Cahuilla Indian called Ramona Lugo or Lubo was the woman after whom the novel was named. She was the widow of Juan Diego, a man who, like Alessandro, had been murdered by an Anglo. In the novel, Alessandro's murder triggered a kind of "ritual death" in Ramona, a sort of coma that leaves her listless and totally dependent. It is a group of Cahuilla Indians who live in the San Jacinto mountains that look after her until Felipe, her foster brother, comes to her rescue. For those searching for the "real" Ramona, Ramona Lugo was therefore a perfect match, both on account of her name and her murdered husband's death, and also of her ethnicity. The attention she received was such, that it only brought her negative and undesirable consequences. For once, "the commodity value of outsiders' interest in her figure helped strain her relations with fellow Cahuillas" (Padget 861). Moreover, photographer George W. James, the author of Through Ramona's Country (1913), failed to treat her with due respect, molesting her even while she was mourning her husband, and condoning his unethical behavior on the basis of a supposedly greater good. In his own words: "It seemed almost a sacrilege to make a photograph of her at this moment [while she is visiting her husband's grave], yet I trust she and the recording angel will consider the kindliness of my heart towards her and her people in balancing the amount of my culpability" (qtd. in Padget 861). It seems that for those profiting from the success of Jackson's Ramona, either through commercial enterprises (railroad companies, real-estate development, etc.) or the commodification of places and individuals, their means were all justified, and respect for California's Indigenous peoples or rigorous history need not apply.

Indeed, California's late $19^{\text {th }}$-century market economy was put to boost the peculiar fantasy heritage built on the basis of Ramona. As Mike Davis has expressed it, Jackson's novel became "a romance that generations of Angelenos," and one could rightly add thousands of tourists from elsewhere too, "have confused with real history" (qtd. in DeLyser 890). In similar terms, writing in 1910 for the opening of Ramona's Marriage Place, journalist Edwin H. Clough underlined people's confusion between fiction and history when it came to Jackson's novel: "The legend of Ramona and Alessandro assumed form and presence as palpable as living things of actual history," and he further elaborated on how "the romance colors the old chronicle and weaves itself on the fabric of fact until it is impossible to discriminate the true from the false, the real from the unreal." In a lighthearted and careless way, though, he wondered, "And what matters it, after all?" (qtd. in DeLyser 900). But to the novel's author who had striven to write "an emotional plea," a work that would do for the Native American what Uncle Tom's Cabin had done for the African American, it would have mattered to see her battle cry turned into a powerful tool for capitalist greed. Many others too, myself included, have mourned the lost opportunity, and have lamented capitalism's capacity to profit from injustice:

Sadly, Jackson's book failed completely as a social problem novel. Instead, its importance to history was that it provided the basis for one of the most important early tourist attractions in southern California. Ironically, as promoters turned the fictional places where Ramona lived into real places, the Mission Indians and 
their problems became increasingly invisible and irrelevant to the larger society. The real tragedy was that the new society coming into being at the turn of the century could so easily integrate a romanticized version of the history of one of its victims into its own sunny success story. (Stevens 167)

\section{RAMONA, THE SILENCED MESTIZA}

One may rightly wonder with Errol W. Stevens what was it that made it possible for the new society coming into being in California at the turn of the century to totally misread Ramona and consequently romanticize the state's victims, its Indigenous peoples, and to capitalize on them while concocting its own sunny success story. Or, more generally, as Douglas Monroy has expressed it: "What is it about humankind that they tend to misread such great novels, and, instead of being roused to action or even mere indignation, personalize the stories and respond in such narrowly self-centered ways?" (135). Throughout this paper, I have attributed the novel's derailing to a number of factors. Of paramount importance was the historical context in which the novel came out, which coincided with California's opening up for massive Anglo settlement thanks to the arrival of various competing railroad companies and the presence of aggressive realestate developers. The author's choice of literary genres for her work can also be ascribed some responsibility, as seen, because regional fiction, the sentimental novel and the romance have not traditionally aided any revolutionary spirit, but have often crashed it under their profit-oriented nature (particularly acute in the case of regional fiction and the romance), their many conventionalisms and, by and large, respect for the status quo. As argued, the state's nascent tourist industry similarly did little to help Jackson's authorial intention flourish; instead, tourism buried it under tons of photographic compositions and rehabilitated buildings that ironically gave verisimilitude to made-up stories, entrenched the neglect for real-life Native peoples, and, paradoxically, encumbered a romanticized version of a past that never was.

Underneath all these factors, though, there lies a coalition of systems and discourses of oppression, that, in my view, more adequately explain Jackson's failed project, i.e., the alliance formed by imperialism, sexism, racism, and capitalism. All four combined can be blamed for the cancelling of Jackson's novel as a call to action on behalf of Native peoples, and for the erasure of Ramona as a potentially subversive mestiza with enough power to unsettle, or at least question, race, gender and class relations. Indeed, under the force of this all-powerful alliance, Jackson's heroine, the symbolic center of the novel, as the title underscores, goes missing, irredeemably lost for the cause of Indigenous peoples' rights.

Undeniably, imperialism plays a major role in suppressing Ramona's potentially subversive power. Land takings, first by the Spaniards and subsequently by white Mexicans and Anglos, as well as enforced labor, genocide and cultural erasure are all at work in a society where eventually Native peoples have it infinitely worse than Californios, as they are left with no place to escape to. Helen Hunt 
Jackson did not spare details on the injustices that Anglo colonization brought to California, both to those of Spanish descent and to Indians. "Nobody need feel himself safe under American rule," denounces Señora Moreno (Jackson, Ramona 15), for whom the Anglo presence has meant a considerable reduction in the number of acres of her hacienda. Father Salvierderra also criticizes Anglo despotism: "We are all alike helpless in their hands, Alessandro. They possess the country, and can make what laws they please" (Jackson, Ramona 66). But Jackson shows that Native peoples fare even worse in this society, since none of them have deeds to prove they own the land they live in, and so they have absolutely no right, and are condemned to constant dispossession and permanent displacement. "We have no right in Temecula," says Alessand ro to Ramona, "not even to our graveyard full of the dead" (Jackson, Ramona 174). Confronted with all these injustices, Ramona naively declares her wish that "it were the olden time now, [...] when the men like Father Salvierderra had all the country. Then there would be work for all, at the Missions. The Señora says the Missions were like palaces, and that there were thousands of Indians in every one of them; thousands and thousands, all working so happy and peaceful" (Jackson, Ramona 223). Alessandro, however, offers a different version: "The Señora does not know all that happened at the Missions," he replies, quick to add: "My father says that at some of them were dreadful things, when bad men had power" (Jackson, Ramona 223-224). These statements prove that Jackson's vision of the Mission system was not totally romanticized. Nonetheless, Alessandro's words do not radically disqualify the Mission system, but only "some" missions where there were "bad men" in power. Thus the novel fails to criticize Spanish imperialism as a whole, as it attributes its shortcomings not to the system in its entirety, but simply to the occasional, and one might say inescapable, existence of "some" "bad" people.

As for Anglo imperialism, Jackson likewise managed to exonerate it in part. The characters of the Hyer family, especially that of Aunt Ri, recently arrived in California from Tennessee, prove to be " $[\mathrm{g}]$ ood-natured, affectionate, humorous people" (Jackson, Ramona 278), capable, even, of abandoning their racist attitudes towards Indians and eventually helping Ramona and Alessandro on many occasions. They are the proof that not all Anglos are exclusively after money, and that not all of them are violent and cruel. However, the fact that in the end a widowed Ramona is reunited with Felipe and both escape to Mexico, where they will marry and lead a better life, clearly suggests that California is no place for either those of Spanish descent or of Native ancestry. For the latter, there is no option but to remain hidden in the mountains, away from water sources, or worse, dead and buried while the crimes committed against them are never to be met with justice. The former, on the contrary, do have a chance to improve their lot. The Moreno lands have been so encroached upon by American settlers that the life the family once led in California is no longer possible for them under Anglo rule. Mexico remains an outlet, though, for those like the Morenos who have the means to acquire lands south of the border.

In terms of gender, Father Salvierderra's words admonishing Alessandro that "[w]e are all alike helpless" are equally proved wrong in the end. Felipe has 
spent months looking for Ramona, only to find her, at the novel's denouement, in an unrecognizable state inside a Cahuilla house: "Was that Ramona,-that prostrate form; hair disheveled, eyes glittering, cheeks scarlet, hands playing meaninglessly, like the hands of one crazed, with a rosary of gold beads?" (Jackson, Ramona 331). Aunt Ri looks after her and helps her recover from her feverish state, in keeping with women's traditional role as caretakers. But it is Felipe that finally takes her away from the Cahuilla people, who rejoice in "her having found such a protector for herself and her child" (Jackson, Ramona 339), as if they were incapable of offering her any comfort. Ramona, for her part, "made no inquires as to Felipe's plans. Unquestioningly, like a little child, she resigned herself into his hands" (Jackson, Ramona 339). Her acceptance of Felipe's power of deliverance and her submission to his leadership are evident. Besides, her willingness to remain silent, emphasized by the narrator's reference to the fact that she "made no inquires" and failed to question his decisions further reinstate her passive role; even more so, her disposition to act "like a child" definitely renders her helpless. At this point, one wonders how José Martí, the Cuban revolutionary and ardent defender of Jackson's Ramona, which he translated into Spanish in 1887, could possibly see the novel's protagonist as "the arrogant mestiza" (358), when, in fact, by the end of the book, her spirit has been utterly broken.

Unlike Ramona, Felipe has raised in stature towards the novel's denouement, first by admitting he was wrong in uncritically accepting his mother's commands, of which he exonerates himself on the pretense that he was "under a spell" (Jackson, Ramona 262), and finally by becoming the rescuer of the damsel in distress par excellence: "A power greater than hers was ordering her way; Felipe was its instrument" (Jackson, Ramona 339). Felipe's power, in this instance, is that of the patriarch who has finally discarded his mother's control and has fully taken his responsibility over his estate and "his" people. Not only that, but he is the white patriarch to whom the victimized mestiza must "[u]nquestioningly" and silently surrender.

As the white patriarch, indeed, he has not only superseded his domineering mother, but he has similarly replaced Ramona's Indian husband, who throughout the novel failed to protect his wife and child, offer them a means of living, a house, healthcare, and dignity. Ramona, the mixed-race heroine, was never fully Indian, in any case. Father Gaspara himself, the Franciscan priest that married Ramona and Assesandro, ponders on Ramona's race: "I don't believe she is a Temecula Indian. [...] She is quite superior to the general run of them" (Jackson, Ramona 250). At the end of the novel, the narrative seems to somehow correct the unsuitable match of such a superior woman to Alessandro, an Indian after all, if an unusual one. By marrying her off to Felipe, of Castilian ancestry, the novel guarantees that Ramona and her second husband's offspring will be whiter and more Moreno-like, or European-like: "Sons and daughters came to bear his name," the narrator foretells in the last paragraph (Jackson, Ramona 353; emphasis added). And though it also advances that the eldest daughter, who was Alessandro's, not Felipe's, remained a favorite of her parents, the fact remains that the narrative has reinstated the white patriarchal order by literally pushing Alessandro to the grave, and foregrounding Felipe's numerous descendants, who will thrive in welcoming Mexico: "The story 
of the romance of their lives, being widely rumored, greatly enhanced the interest with which they were welcomed" (Jackson, Ramona 353). ${ }^{15}$

In this new Mexican context, Ramona is said to "doubt her own identity" (Jackson, Ramona 353), which may just as well be so, given the multiple uprootings she has experienced in her life, as well as the various identities she has been imposed: first, that of a supposedly white woman of Spanish descent, a "Spanish señorita"16 living on a Californio ranch in Anglo California; second, that of a mixed-race woman married to an Indian (Alessandro) and forced to constantly abandon their land; finally, that of a mestiza married to a white man (Felipe), both residents in Mexico. Her identity confusion is only natural, since her final marriage to Felipe, that is, "the way in which she is insulated within a high-caste 'Spanish' family[,] suggests that Ramona's mestiza identity is denied" (Padget 867). Through Ramona's capitulation to the white patriarch, the symbolic center of the novel can be said to have gone missing, in as much as the Indian traces in both Ramona and her offspring to Felipe are whitewashed, diluted among that "high-caste, 'Spanish' family" that her second husband has given her.

In terms of the novel's racial assumptions, it is also of great significance that Ramona and Felipe, an inter-racial couple, are sent off to Mexico, where they are allowed to marry, miscegenate, and lead a happy life, thus leaving the US symbolically empty of Californios like Felipe and crosses like Ramona (Natives like Alessandro have been previously, and conveniently, wiped out). The US is now for whites only, "free from the insidious atavistic influence of mixed blood" (Gonzalez 454). According to Margaret Jacobs, Ramona and Felipe's escape to Mexico would suggest that "the mixings of certain kinds of blood," namely that of "Spanish and Indian" (218-219), are a non-desirable mix. Once the Anglo empire has rid of them, it can proceed to advance across the southwest, unimpeded by the presence of inferior races and the threat of miscegenation. This is how Jackson's Ramona ends up fostering "a gendered and sexually charged Manifest Destiny ideology" (Venegas 64) despite its efforts to the contrary. ${ }^{17}$

15 Robert McKee Irwin has argued that given Ramona's mestiza identity, her decision to identify as an Indian and to marry an Indigenous man "would hardly have been looked upon favorably by urban elites in late nineteenth-century Sonora or Baja California," as "belief in white supremacy ruled in certain social strata throughout the borderlands region" (559). This points to the racism that Ramona would have encountered in historical Mexico, which further compromises the verisimilitude of Jackson's novel, whose happy ending is predicated on Mexico's welcoming attitude towards Felipe, and, more problematically, his marriage to a mestiza.

16 “Despite Ramona's Indian blood, Jackson constructs her culturally as a fully assimilated Spanish señorita. As a proper 'Spanish' señorita she has attended private Catholic school in Los Angeles and learned all the skills characteristic of a refined señorita: embroidery, weaving, and painting. Even after she leaves her adopted Spanish family and goes Native with her love, Alessandro, she acts according to her Spanish upbringing" (Venegas 76).

${ }_{17}$ Of equal relevance in this racialized construction of a Manifest Destiny ideology is the characterization of Ramona's Native mother, who is completely silenced in the novel, and of the saucy Mexican maid, Margarita, who is presented as being "immoral and sexually and racially impure" 
As seen, in Jackson's novel imperialism, sexism and racism are conveniently combined to aid the capitalist system in a number of ways. At the end of $19^{\text {th }}$-century California, agents of capitalism, that is, real estate developers, railroad companies, and owners of various tourist businesses (hotels, souvenir shops, etc.) took advantage of gullible and uncritical consumers, mostly uprooted Midwesterners who were eager to buy a piece of land in sunny California and were consequently reluctant to admit that the land was not empty, though they were ready to accept that, if necessary, if should be emptied. These business transactions required dispensable victims, i.e., Californios, most of whom were of mixed-race descent, ${ }^{18}$ and, above all, Native Americans, who were even more vulnerable. ${ }^{19}$ A necessary accomplice was added to this in the form of Ramona, the novel, the myths and stories it gave rise to, as well as the photographs that paradoxically granted it verisimilitude, and even the architecture that was purportedly inspired in Mediterranean building techniques in an attempt to link Southern California to its romanticized Spanish past. ${ }^{20}$ As Douglas Monroy has put it:

Real estate developers and railroad companies captured the story of Ramona and used the compelling myths it contained about the halcyon days of old California to sell house plots and train tickets to newcomers. Thus it was that people uprooted from the Midwest could find rootedness in California as they adopted the captivating myths of the new place, stories that Ramona helped generate. To this day developers use whimsical Spanish names with faux Mediterranean architecture that recall Californio society to sell real estate. (Monroy 137-138)

Supported by the inter-locking discourses of imperialism, sexism and racism, the capitalist system virtually erased the Native presence in California. Meanwhile, literature and the arts, despite Jackson's intention to use her novel to promote social justice, became accessory in imperialist and capitalist ruthless practices. In this way,

(Venegas 79). Moreover, the representation of Californios as "idle, illiterate, semi-savage Mexicans" builds up a "hidden text shrouded in romance and nostalgia" and proves to Anglo readers of the novel that Californios "were surely unable to develop the land to its full potential" (Venegas 80), which further justifies Anglo rule in California.

18 According to Glen Gendzel, among the Californios, "fullblooded Spaniards were greatly outnumbered by Mexicans of mixed descent-mestizos who combined European, Native American, and African ethnicities" (75). Del Castillo concurs that Californios, "wealthy families who had been given large grants of land by the Spanish and Mexican governments," may have "considered themselves 'Spanish' but in reality they were almost all mestizos, having a mixed cultural and racial heritage" (3).

19 American rule in California resulted in three statutes that vitally affected Native Americans: no Indian could testify in court; Indians might be declared vagrants upon the petition of a white person, and Indian children could be forced by ranchero owners, or dons, to become apprentices with the "consent" of their parents (Dobie 95).

20 The popularity of "Mission Revival architecture" in California, beginning in the $1880 \mathrm{~s}$ and continuing through the early $20^{\text {th }}$ century, gave rise to the wide-spread use of "the stucco, tiles, gables, and towers of the missions," which were "copied in thousands of houses, hotels, office building, schools, and train stations around the state" (Rawls 352). 
Ramona was turned into "a boosterist device, rather than a battle cry" (DeLyser 893), one which condemned Indigenous voices to the margins in much the same way as Alessandro's dead body and Ramona's abated mestiza spirit were both buried under California's sunny skies. If there is a lesson to learn from Jackson's Ramona, it could well be what Chicana writer Cherríe Moraga concludes in her 2019 memoir Native Country of the Heart, a poignant reflection on her mother's life across the US-Mexican border and her own mestiza identity:

There is no religious justification for the Spanish mission system, which effected a genocidal practice of slavery, dislocation, disease, and rape against Native Californians, and laid the groundwork for the two centuries of Native obscurity that followed. There is only greed.

There is no justification for the betrayal of the promises of Mexican Independence against the Tongva, the Chumash, the Cahuilla... There is only greed.

Since the arrival of the gringo in the mid-nineteenth century, it is first and last greed that has whitewashed the entire history of Native California, even as it walks still in the bodies of its "Mexican" descendants.

There is no justification, but there is so much need for reckoning... (238)

There is, indeed, much need for reckoning in the history of California's Native peoples, but before embarking upon it, one should realize the limitations of a social and political vision that, like Jackson's, comes from "the center." Despite her good intentions, her perspective and others like hers may well be said to be inevitably laden with systems and discourses of oppression. These systems permitted the author to barely scratch the status quo, if at all, or, worse, allowed her to contribute to the entrenchment of economic, sexual and racial inequalities, and needless to say, to the silencing of the mestiza spirit. Had Jackson's project been fueled by the latter, the results would have been, presumably, less disappointing. Indeed, as Yolanda Venegas has argued, when it came to confronting the tyranny of the church and state, "Native women played a pivotal role in resistance activities" (73), and, as proved by the case of Toypurina (1760-1799), a Tongva medicine woman from the vicinity of San Gabriel Mission who organized the 1785 revolt against Spanish colonial domination, they did so by resorting to non-Western strategies and by refusing to give up on their identities. Ramona, surely, would have fared better as a role model for women of mixed ancestry if she had followed Toypurina's example instead of surrendering her mestiza spirit to empire and romance.

REVIEWS SENT TO AUTHOR: 13-3-2020; REVISED PAPER ACCEPTED FOR PUBLICATION: 10-7-2020 


\section{WORKS CITED}

Arlt, Gustave O. "California’s Literary Women." The Historical Society of Southern California Quarterly 36/2 (1954): 99-114.

Byers, John R. Jr. “Helen Hunt Jackson (1830-1885).” American Literary Realism, 1870-1910 2/2 (1969): 143-148.

Byers, John R. Jr. “The Indian Matter of Helen Hunt Jackson's 'Ramona': From Fact to Fiction." American Indian Quarterly 2/4 (1975-1976): 331-346.

del Castillo, Richard Griswold. "The del Valle Family and the Fantasy Heritage." California History 59/1 (1980): 2-15.

DeLyser, Dydia. "Ramona Memories: Fiction, Tourist Practices, and Placing the Past in Southern California." Annals of the Association of American Geographers 93/4 (2003): 886-908.

Dobie, J. Frank. “Helen Hunt Jackson and 'Ramona.” Southwest Review 44/2 (1959): 93-98.

Gendzel, Glen. "Pioneers and Padres: Competing Mythologies in Northern and Southern California, 1850-1930.” Western Historical Quarterly 32/1 (2001): 55-79.

Gillman, Susan. "Ramona in 'Our America.' " In José Martí's “Our America”: From National to Hemispheric Cultural Studies (New Americanists). Eds. Jeffrey Belnap and Raúl Fernández. Duke University Press, 1998. 91-111.

Gonzalez, John M. “The Warp of Whiteness: Domesticity and Empire in Helen Hunt Jackson's 'Ramona'." Literary History 16/3 (2004): 437-465.

Havard, John C. "Sentimentalism, Interracial Romance, and Helen Hunt Jackson and Clorinda Matto de Turner's Attacks on Abuses of Native Americans in Ramona and Aves sin nido." Intertexts 11/2 (2007): 101-121.

Irwin, Robert McKee. "Ramona and Postnationalist American Studies: On 'Our America' and the Mexican Borderlands.” American Quarterly 55/4 (2003): 539-567.

JaCkson, Helen Hunt. "Report on the Condition and Needs of the Mission Indians of California, made by Special Agents Helen Jackson and Abbot Kinney, to the Commissioner of Indian Affairs," sent from Colorado Springs, Colorado on July 13 ${ }^{\text {th }}$, 1883. Appendix XV in Mrs. Jackson's A Century of Dishonor. Roberts Brothers, 1890. 458-514.

JaCkson, Helen Hunt. A Century of Dishonor. Sketches of the United States' Dealings with Some of the Indian Tribes. University of Oklahoma Press, 1995 (1881).

Jackson, Helen Hunt. Ramona. The Modern Library, 2005 (1884).

Jacobs, Margaret D. "Mixed-Bloods, Mestizas, and Pintos: Race, Gender, and Claims to Whiteness in Helen Hunt Jackson's 'Ramona' and María Amparo Ruiz de Burton's 'Who Would Have Thought It?" Western American Literature 36/3 (2011): 212-231.

Marsden, Michael T. "A Dedication to the Memory of Helen Hunt Jackson: 1830-1885." Arizona and the West 21/2 (1979): 109-112.

Martí, José. Introduction to the 1888 Spanish Edition of Helen Hunt Jackson's Ramona, translated and published by José Martí. English translation by Esther Allen. In Ramona. The Modern Library, 2005. 357-359.

Mathes, Valerie Sherer. "Helen Hunt Jackson: Official Agent to the California Mission Indians." Southern California Quarterly 63/1 (1981): 63-82. 
Mathes, Valerie Sherer. “Helen Hunt Jackson and the Ponca Controversy.” Montana: The Magazine of Western History 39/1 (1989): 42-53.

Mathes, Valerie Sherer. "Nineteenth Century Women and Reform: The Women's National Indian Association." American Indian Quarterly 14/1 (1990): 1-18.

Mathes, Valerie Sherer. "The California Mission Indian Commission of 1891: The Legacy of Helen Hunt Jackson.” California History 72/4 (1993-1994): 338-359.

Mathes, Valerie Sherer. Helen Hunt Jackson and Her Indian Reform Legacy. University of Oklahoma Press, 1997.

Mathes, Valerie Sherer. "Helen Hunt Jackson and Southern California’s Mission Indians.” California History 78/4 (1999-2000): 262-273.

Mathes, Valerie Sherer. “New York Women and Indian Reform.” New York History 94/1-2 (2013): 84-110.

Monroy, Douglas. "Ramona, I Love You." California History 81/2 (2002): 134-155.

Moraga, Cherríe. Native Country of the Heart. A Memoir. Farrar, Straus and Giroux, 2019.

Nevins, Allan. "Helen Hunt Jackson, Sentimentalist vs. Realist." The American Scholar 10/3 (1941): 269-285.

PAdget, Martin. "Travel Writing Sentimental Romance, and Indian Rights Advocacy: The Politics of Helen Hunt Jackson's Ramona." Journal of the Southwest 4/4 (2000): 833-876.

Ramona. Dir. Alberto Cortés Calderón. 2000. Televisa. Mexico. Telenovela.

Ramona. Dir. D. W. Griffith. 1910. Biograph Company. USA. Film.

Ramona. Dir. Donald Crisp. 1916. Clune Film Producing Company. USA. Film.

Ramona. Dir. Edwin Carewe. 1928. Inspiration Pictures. USA. Film.

Ramona. Dir. Henry King. 1936. Twentieth Century Fox. USA. Film.

Ramona. Dir. Víctor Urruchúa. 1946. Promex. Mexico. Film.

Ramona. Screen Guild Theater. 1945. Radio broadcast. https://free-classic-radio-shows.com/Drama/ Screen-Guild-Theater/1945-1946/1945-04-30-ep243-Ramona/index.php. Accessed 18.7.2019.

Rawls, James J. “The California Mission as Symbol and Myth.” California History 71/3 (1992): 342-361.

Rojek, Chris. "Indexing, Dragging and the Social Construction of Tourist Sights." In Touring Cultures: Transformation of Travel and Theory. Eds. Chris Rojek and John Urry. Routledge, 1997. 52-74.

Smith-Baranzini, Marlene. "Helen Maria (Née Fiske) Hunt Jackson: An Introduction to 'Ramona' and its Author." California History 77/3 (1998): 156-157.

Stevens, Errol Wayne. "Helen Hunt Jackson's Ramona: Social problem Novel as Tourist Guide." California History 77/3 (1998): 158-167.

Stowe, Harriet Beecher. Uncle Tom's Cabin. Ed. Elizabeth Ammons. Norton, 1994 (1852).

The Ramona Pageant. Dirs. Garnet Holme (1923 adaptation) and Stephen Savage (2015 update). Hemet, California. Outdoor play.

Venegas, Yolanda. "The Erotics of Racialization: Gender and Sexuality in the Making of California." A Journal of Women Studies 25/3 (2004): 63-89.

Whitaker, Rosemary. “Helen Hunt Jackson (1830-1885).” Legacy 3/1 (1986): 56-62. 
